\title{
TC22 Allele
}

National Cancer Institute

\section{Source}

National Cancer Institute. TC22 Allele. NCI Thesaurus. Code C129380.

Human TC22 allele is a variant form of the human TPM3 gene located 1q21.2 and is approximately $39 \mathrm{~kb}$ in length. This allele, which encodes tropomyosin alpha-3 chain isoform 3, may be involved in carcinogenesis in the colon. 